\title{
Theoretical and methodological guidelines for transnationalization and integration process managing in Eurasian Economic Union agricultural sector
}

\author{
Sergei Schitov ${ }^{1, *}$ and Nadezhda Likholetova ${ }^{1}$ \\ ${ }^{1}$ Federal Rostov Agrarian Scientific Center (FRASC), Rassvet, Rostov region, 346735, Russia
}

\begin{abstract}
Integration processes in the EAEU are currently developing against the backdrop of new global geo-economic, scientific, technological, and socio-economic challenges, and there is a constant active comprehensive development of cooperation with external partners, which is one of the important components of the successful functioning of the EAEU. An urgent task is to develop theoretical and methodological provisions for managing the processes of transnationalization and integration of the agricultural sector of the countries of the Eurasian Economic Union. To this end, a system of indicators for assessing the effectiveness of measures to manage the processes of transnationalization in agriculture was formed. The dependence of development of the industry on an effective program for adapting organizations to new economic conditions was established, which should take into account the complex of processes in the market, political, economic and other factors affecting the effectiveness of activities and make provisions for managing the processes of transnationalization in agriculture. The use of indices and indicators of transnationalization and integration will make it possible to monitor and exert a managerial impact on the integration processes and the interpenetration of economic complexes of the Union countries in the context of inclusion in global economic systems.
\end{abstract}

\section{Introduction}

Today, the processes of transnationalization are associated with a number of factors, such as the deepening of the international division of labor, increased competition in world markets, the intensification of the processes of globalization and the internationalization of production forces, and the strengthening of ties in international trade and global entrepreneurship. The global stage of economic integration is directly related to the multifaceted process of internationalization, which is the process of expanding and deepening global economic ties, the mobility of factors and means of production (at the macro level) and the participation of companies in international operations (at the micro level).

* Corresponding author Stiffx1@yandex.ru 
Integration should be considered as a fundamental platform for the internationalization of the economic sphere, the objective need to strengthen the interaction of national economic systems and the implementation of coordinated economic policies at the national and global levels in various forms (free movement of goods, customs unions, market, economic, monetary and political unions) [1].

Internationalization as a process of expanding the international system of economic relations between national economics, in turn, is based on the transnationalization of entrepreneurial activity, when there is a deepening of production processes, scientific and technical specialization and cooperation. Based on the above, it is possible to identify the general economic characteristics of integration, the most significant for the transnationalization of commercial activities:

- research of effective forms of international regulation of world economic relations;

- creation of integral regional blocks of the international economic complex of the general scale and reproduction structure;

- increasing opportunities for the international circulation of goods, labor and capital by removing administrative and economic barriers;

- equalization of the level of economic development of the member states of integration associations through the international unification of the operating conditions.

Currently, the types of relations between TNCs and the national economy can include the following types: ethnocentric, polycentric, regioncentric, and geocentric. The selected principles were largely influenced by the following key principles of the transnationalization of production activities:

- the transformation of the world economy to the sixth technological order with its systematic digitalization;

- diversification of the supranational capital structure in the country with depersonalization of assets;

- vertical spatial integration of clusters in transnational economic entities;

- creation of new regional centers for attracting global investment capital.

In course of the study, the authors have compiled a theoretical and methodological basis for the transnationalization of production, schematically presented in Figure 1.

The ideology of transnationalization reflects the main features and mechanisms of the process, the economic assessment of which allows us to implement a comprehensive approach to improving the efficiency of integration processes. On the one hand, these principles are an expression of the modern processes of integration and globalization; on the other hand, they act as regulators that form the modern vector of development.

Global trends in the internationalization of production and capital, as well as the liberalization of foreign trade, have allowed TNCs to take a central place in the system of world economic relations [2].

The diversification of the structure of transnational capital by country and the formation of a class of international owners is a manifestation of ethnocentrism and polycentrism. The pace and structure of the transnationalization of commercial activities in accordance with this principle is dynamic and is being transformed in the context of the priority increase in the capital of national companies, which, by increasing their competitiveness, strengthen their positions at the international level. 


\section{Principles of transnationalization of production}

$\left.\begin{array}{|c|c|c|c|c|}\hline \begin{array}{c}\text { Diversification of } \\ \text { the country's } \\ \text { capital structure } \\ \text { of transnational } \\ \text { production }\end{array} & \begin{array}{c}\text { Formation of new } \\ \text { centers of capital } \\ \text { accumulation and } \\ \text { investment }\end{array}\end{array}\right] \begin{gathered}\begin{array}{c}\text { Transition to } \\ \text { the sixth } \\ \text { technological } \\ \text { order }\end{array} \\ \mid\end{gathered}$

Forms of relations between TNCs and external systems

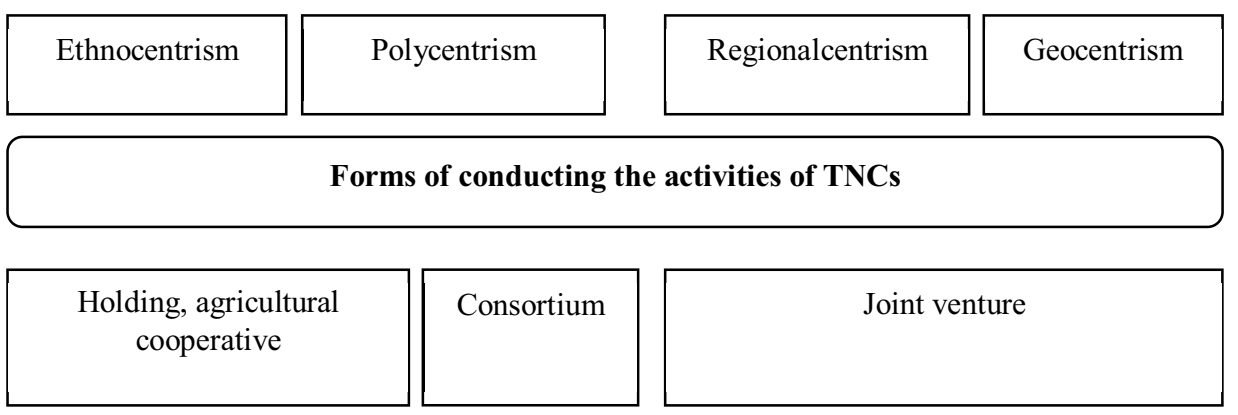

Tools for implementing the principles of production transnationalization

Attracting foreign direct investment

\section{Digitalization of the economy}

Access to global markets
Ensuring global competitive advantage

Fig. 1. Theoretical and methodological basis of transnationalization of production. Note: developed by the authors.

Vertical (cluster) integration of transnational entities as a principle of transnationalization determines the growing influence of the effects of polycentrism and regioncentrism. This has led to an increase in the size and complexity of international companies and an increase in the geographical scope of activities. At the same time, the transnationalization of production is the result of increased financial and investment activity, since TNCs are not only the backbone of the economies of developed countries, but also an important catalyst for the development of emerging economies. The impact of this principle increases the effectiveness of the scientific and technical process, which in turn leads to the emergence of new types of corporate structure of international companies, especially vertically integrated ones. International holding companies are emerging that operate in several national markets and seek to adapt their products and marketing strategies to local conditions through the management capacity of their branches. The described processes activate the process of transnationalization of entrepreneurial activity and the creation of prerequisites for the expansion of a single global market and information space [3].

The implementation of the principle of forming new regional centers for the accumulation of investment capital determines the forms of regioncentric and geocentric relations: the transformation of the scale of intra-corporate relations, which acquire the 
status of regional (global), as well as the intensification of the processes of internationalization of international business activity on the platform of innovative developments of logistics and commercial systems.

One of the main principles of transnationalization today, in the context of globalization - is the transition of the world economy to the sixth technological order with its systematic digitalization. The content of international business operations takes the form of system informatization and digitization, from the idea to the actual result, and becomes the core of international business, its center, around which all interests, decisions and strategies revolve.

As a result of transformation of the economy the application of transnational monopoly capital leads to mergers and acquisitions, appear of territorial and industrial groups, crossshareholding, competition between TNCs and other international economic actors increases, moving from national to international level. As a result, the subjects of the world economy are changing their behavioral function, new markets are emerging, there is a need for international and supranational regulation, increased influence on multinational corporations, the level of aggressiveness of competition and its multipolarity.

Markets dominated by multinational corporations are characterized by their monopolization or, in most cases, oligopolization. The dominant position in corporate strategies of monopolization of capital and production, mergers and acquisitions is an effective form of capital concentration and centralization of TNCs. This, in turn, implies strengthening the competitive leadership of TNCs in the relevant segments of the global economy [4].

In the context of the formation and development of global markets, it is possible to distinguish the main strategies of TNCs: global, transnational, duplicative and multiposition. A global strategy requires TNCs to achieve high levels of efficiency at the expense of transnational activities. TNCs view the global economy as a single market, aiming to create standardized goods and services that meet consumer needs in as many countries as possible.

The commitment to a transnational strategy ensures both increased efficiency through globalization and a high degree of adaptation to local conditions. As part of the business replication strategy, TNCs use the core skills and experience gained in the countries of origin, or competitive advantages, as the main tool for expanding international activities in the global market. The use of a multi-position strategy is typical for a number of relatively independent TNCs operating in a remote local market through subsidiaries [5].

It follows from this that the principles of transnationalization of corporate activities, by their economic nature, represent a system of prevailing trends in the global economic system that determine the structural transformation of the economy and business activity, both at the basic level and at the level of relationships of a more complex order, with its reorientation to a completely new innovation, financial, production and management platform.

The degree of transnationalization of agriculture depends on the conditions of functioning and development of TNCs in the agricultural sector. Despite the large financial and material resources, not all TNCs in the Russian market are achieving significant results: some are leaving the market or closing their production facilities to focus exclusively on exports. This situation is also typical for the agri-industrial complex.

$\mathrm{TNC}$ in the agricultural sector shows unequal activity in the creation and development of different types of partnerships and inter-firm networks, which is influenced by the institutional environment (in the country where the head office is located, and in the host countries). Thus, both inter-organizational value-added relationships and the potential for cost savings are important. 
Most often, TNCs form a network of divisions around themselves, based on the principles of their own dominance, close the decision-making centers related to the product range and production, unify quality standards and forms of relationships of all network participants.

The analysis of the business environment of the EAEU countries revealed a number of significant characteristics that affect the activities of TNCs and require adaptation of their strategy, namely: a high level of uncertainty, bureaucratic barriers, frequent changes in legislation and legal norms, risky investments, and difficulties in agreeing on the placement of new enterprises [6]. Such a specific institutional environment makes it necessary to change the management strategies of TNCs in the agricultural sector in the space of the EAEU countries.

\section{Research methodology}

A review of methodological approaches to managing the processes of transnationalization has revealed that today there are well-known and calculated indices of transnationalization, which can be of two types: the index of internationalization of companies and the index of transnationalization of countries. Taking into account the specifics of the interaction of the EAEU countries, it is necessary to develop indicators that take into account the peculiarities and trends of the transnationalization and integration of the agricultural sector of the Union countries.

Before systematizing the indicators for assessing the effectiveness of the transnationalization of the EAEU countries agricultural sector, it is necessary to summarize the general management strategies of the TNCs of the EAEU countries in the context of agri-food policy.

There are the following types of management strategies for TNCs of the EAEU countries in the context of agri-food policy:

1. The market entry strategy is an investment model of market access, which is implemented through the acquisition of domestic companies or through the organization of joint production enterprises.

2. Building partnerships. Creating partnerships involves overcoming mutual distrust of partners, linking and agreeing on schedules, the need to constantly coordinate all the details with the CEO, the long term of concluding contracts, and the difficulties of integrating into existing partner networks.

3. Personnel management and marketing activities. With regard to the main risks that hinder the development of inter-firm relations between the EAEU countries, the most painful for companies are the problems of reliability, quality of products and services offered by the EAEU countries, as well as the lack of sufficient experience in business cooperation in the field of cooperation.

The main features of the management of TNCs in the Russian market and the factors influencing their development are as follows: local production and product adaptation, organization of the service, cooperation with Russian companies, constant innovation, early entry into the market, a high level of independence of local divisions, building interaction with local and federal government bodies [7,8].

It is in Russia's national interests to strengthen relations with its closest historical partners (the CIS countries). However, this does not exclude the possibility of joining any of the states created after the collapse of the USSR to the technological chains of foreign TNCs or independently creating supranational systems under the control of domestic capital. Here, increasing competitiveness and subsequent positive changes in the structure and volume of production are of fundamental importance. If these problems are successfully solved, it becomes possible to choose the most preferred option for the 
transnationalization of production, which guarantees the maximum return on the invested capital. Therefore, in our opinion, simplified and one-sided approaches should be avoided in the conceptual justification of the prospects for the development of transnational business.

Russia's economic strategy should take into account the development trends that play a dominant role in the formation of the modern system of the world economy. In this regard, the Russian economy faces two complementary goals:

-penetration into the world markets based on the supply of high-tech products that have no analogues; organization of branches abroad based on new methods of production of material goods;

- the constant convergence of various technological paradigms, the transition from rigid vertical production links to flexible horizontal ones as a result of the inclusion of elements of a new technological platform, in particular, information exchange systems, in all parts of the economic structure. The potential for future development is created by creating a variety of horizontal technological chains, including intra-economic links, while going beyond the national economy [9].

In the context of the problems outlined above, we will highlight the following points of the provisions on the management of the processes of transnationalization and integration of agriculture in the space of Russia and the EAEU:

1. Let us denote the statement about the expediency of creating an interstate agroindustrial corporation with branches (representative offices) in the EEA countries, in order to get a major player in the market of agricultural products, able to compete with foreign TNCs.

According to the study, multinational companies associated with agricultural production showed the greatest resilience during the financial crisis. In this sense, it can be assumed that a state-owned company established in the field of agriculture will have a sufficiently high stability in conditions of instability, and will be able to fully realize its economic potential.

Other arguments in favor of creating a state corporation in the field of agriculture are the presence of large domestic markets both in the Russian Federation and in the Middle East and Asian partners (Turkey, China and India), which, given their potential, certain demographic conditions may surpass other countries. Labor costs in the industry, as a rule, are relatively low compared to other sectors of the economy and amounted to an average of 28,400 rubles in 2019 , compared to 43,445 rubles of average monthly payments in the country.

According to the latest data from the Valdai Club, the center of the world economy tends to move to the Asian region. It should be noted that Russia is not yet able to fully realize its potential due to infrastructure constraints and a difficult demographic situation. The existing prospects can be realized through the implementation of the Siberia project. Its principle is active investment in infrastructure development, including large-scale projects such as deep processing plants and the creation of Asia-oriented agriculture and other capital-intensive industries. This will require the development of a targeted state policy to attract Russian and foreign investment, provide benefits and guarantees. As a result, China and other Asian countries will have access to Russian high-quality raw materials and agricultural products, the relative shortage of which is growing in Asia. Demographic problems, expressed by a shortage of labor, can be partially solved by labor migrants from China. One of the competitive advantages in this area is the availability of rich natural resources, as well as large undeveloped areas of arable land. The appearance of such an entity as a corporation with public-private capital on the market will give an impetus to the development of close industries for the production of agricultural machinery, fertilizers, etc., as well as second-and third-level contractors [10]. 
An agro-industrial enterprise based on public-private capital as an instrument of state development should include the following related elements:

- agricultural land;

- fertilizer producers;

- a specialized agricultural bank or other financial institution attracted to provide targeted loans at a preferential rate;

- plants for the production of specialized equipment;

- agricultural research centers and laboratories, universities;

- human resources;

- transport companies;

- associations of agricultural producers, agricultural enterprises, agricultural holdings, cooperatives [10].

The stages of transformation of Russian economy spheres are shown in Figure 2.

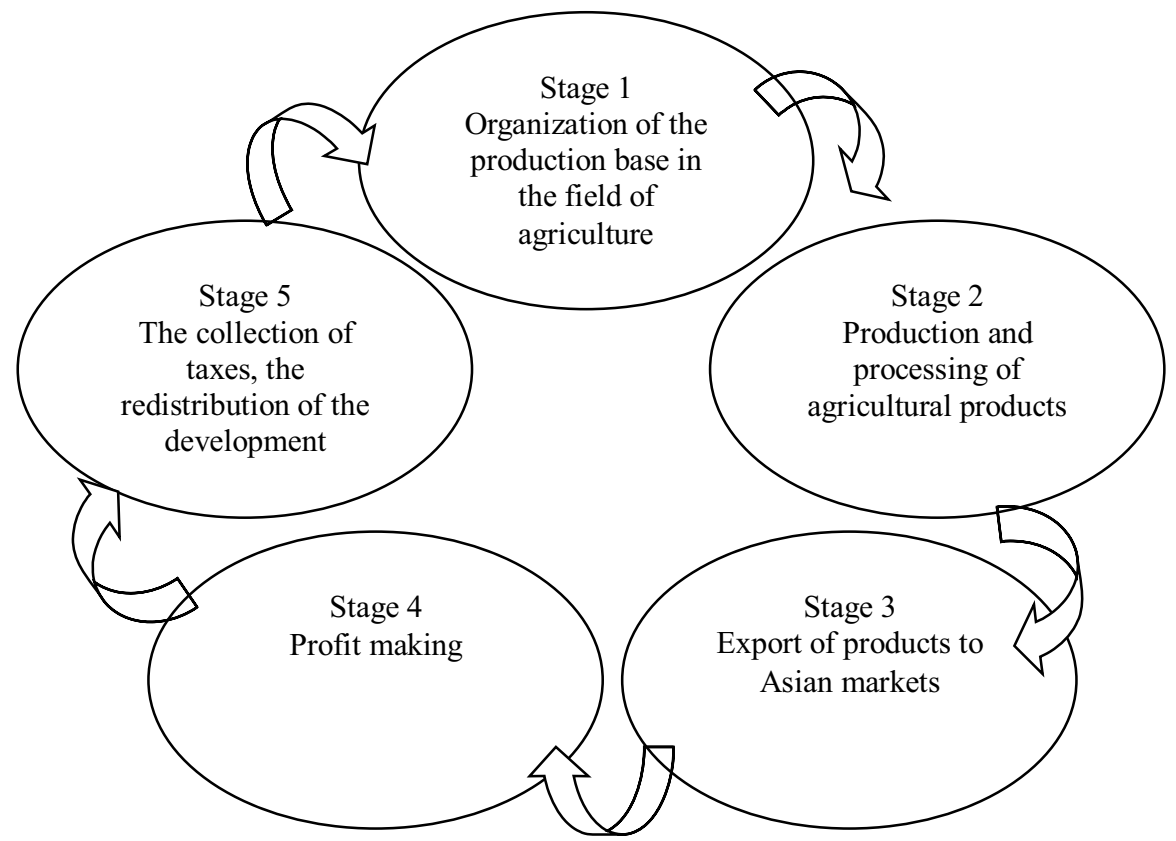

Fig. 2. Stages of transformation of the spheres of the Russian economy. Note: developed by the authors.

At the first stage, the problems associated with the organization of the resource and raw material base of production are considered. Production of products should be carried out both at the expense of public funds and at the expense of personal funds of farms. The main focus should be on the second group.

This type of cooperation will help to mobilize human, technical and economic resources and provide access to affordable credit. More importantly, the project will create a transport network for both domestic and foreign markets. Private producers should then become the backbone of agricultural production, as they are more sensitive to changing market conditions and therefore more resilient.

The main problem that we have to face is getting cheap loans, as well as the problem of delivering the goods sold to the points of sale [11].

The second stage is the production of agricultural products. It is important to correctly assess the potential of domestic and external demand, for example, using indicators of the volume of imported and exported products, as well as studying the dynamics of prices. 
The potential for "external demand" in Asian markets should be measured using indicators of agricultural imports from Asian countries, as well as the production potential in the region. At the same time, it is necessary to continue the development of foreign markets, as this is the main factor of structural modernization [11].

At the third stage, it is necessary to support the sales of manufactured products in the domestic and foreign markets. This is particularly important because it reduces operational and transport logistics costs and helps small producers sell their products. Such policies can lead to a strengthening of the trade balance and structural changes in the economy $[11,12]$.

The creation of specialized committees involves protecting the interests of domestic producers, as well as leveling the impact of technical and non-tariff restrictions on products. This possibility exists in connection with Russia's participation in the WTO.

The fourth stage is the search for sales channels. The Asian approach to entrepreneurship is aimed at maximizing profits, with the main goal being to significantly increase sales. This could be facilitated by taking into account the traditions and consumption patterns of the countries of the region, as well as the development and implementation of a specific marketing strategy. In addition, it is necessary to strictly adhere to the Asian approach to business, namely, to establish long-term business and less formal relationships with strategic partners.

The fifth stage of the creation of an Interstate Corporation should include an assessment of the financial resources provided to small and medium-sized farmers for the development of production, technical capacity-building, and scientific research, taking into account the actual conditions for repayment of loans. At this stage, the planning of investment activities in the areas is organized, and the steps within the 1-4 stage are calculated for the next period. Then the cycle repeats.

\section{Results}

1. Using the domestic potential of the economies of the EAEU countries and Russia is a priority in the creation of state-owned companies, which leads to an increase in their competitiveness compared to providing access to foreign multinational corporations to the domestic market, since they often try to attract foreign equipment manufacturers and resource suppliers. Thus, foreign multinational corporations receive additional profits without making positive structural changes in the structure of Russian production and exports.

2. In the Rostov region, in order to model the provisions of state regulation of the process of transnationalization, it is advisable to use a number of methods and tools of state influence. In this context, the target function in the work of the mechanism determines the solution of tasks related to supporting the formation and development of large farms with the prospect of their further transnationalization using the method of program-target regulation in two directions: regulation of organizational and economic interaction between national and foreign TNCs; improving the institutional environment for the development of the transnationalization process.

The policy of the current system of regulation and coordination of foreign economic activity of exporting companies does not reflect the strategic directions of creating conditions for the development of national TNCs, without which it is impossible to radically reform the grain sector of the region. The government does not have a specialized coordinating body at both the federal and regional levels that would regulate the domestic market and grain exports.

We believe that the creation of the Coordinating Committee for Monitoring and Regulating the Activities of Grain Exporters under the Rostov Regional Administration is a promising way to solve the problems of managing the processes of transnationalization. 
Members of the Committee may be experts of the ministries and departments of the Administration of Rostov region, responsible for the development of foreign economic relations and foreign economic activity of enterprises and organizations of economic security. The functional responsibilities of the committee should be to monitor the situation on the regional, national and federal grain markets, adopt legislative measures, provide organizational and economic support for grain exports, restrict monopolistic activities and promote competition in the grain market.

In addition, it seems advisable to implement a set of measures of state regulation of the process of transnationalization of export-oriented grain production, the implementation of which does not involve" infusions " of significant investments, in particular: the creation of a single set of rules for grain trade, the activation of trade missions abroad to promote domestic grain and its processed products to the markets of other countries, bringing domestic grain quality control standards in line with international standards.

3. International experience points to the feasibility of allocating investment banks and investment funds specializing in the financing and management of long-term investments as part of financial institutions. We are referring to the task of developing a network of specialized investment banks with significant state participation (at least 30\%), where it is possible to accumulate the resources of long-term bond loans.

Various organizational schemes for the functioning of investment banks can be used. It seems appropriate to take into account foreign experience. For example, in France, specialized financial institutions that take on some of the investment risks receive bonification from the state - the actual provision of loans at a reduced discount rate. In Japan, all government support for the industrial sector, including construction, occurs mainly through the bank of the Ministry of Industry and Trade [12].

In our opinion, the concept of providing a loan at a future cost, aimed at increasing the country's potential in the field of advanced technologies, is interesting. Investments should go hand in hand with the introduction of promising resource-efficient and environmentally friendly technologies that reduce energy consumption per unit of production and focus on the most rational use of the region's resource base. At the same time, investment projects must pass state expertise on the innovation of the technologies used and compliance with environmental and hygienic requirements.

4. Great importance is the extension of the official statistical database on indicators of transnational corporations in Russia. In our opinion, the most important information that should be made public is property data. It is currently difficult to obtain information about the owners and ultimate beneficiaries of TNCs. In addition to information about the owners, it is also necessary to publish the company's data on investments, sales figures, activities, employment structure, resource use, etc. This will create a basis for analyzing the current trends in the transnationalization of production in Russia and will allow us to evaluate the decisions made by multinational companies in terms of their impact on the social sphere. It is important to ensure data verification. By analogy with Western countries, it is advisable to issue a report with annually updated data on the production and economic activities of firms, certified by an independent auditor.

5.In addition to the above, the entrepreneurial culture and the quality of management are important for improving the efficiency of the transnational activities of Russian TNCs. The problem of involving Russia's intellectual potential in transnational production systems can be solved by creating a modern structure of a national technology broker, such as the British Technology Group (UK), the state agency ANWAR (France). They support the creators of intellectual products, formulate and grant copyrights, and then distribute the proceeds from the joint commercial implementation of technological innovations to all participants in the process of their joint creation. 
6. In general, the tasks of state regulation of transnational business can be formulated as follows: using the cross-border potential of production to achieve long-term economic growth, improve the standard of living of the population and minimize negative consequences.

The impact on transnational business activities is carried out within the framework of the general economic policy, which includes structural (production, scientific and technological development) and social blocks, including measures in the field of investment, production and finance, monetary policy. Macroeconomic management, which defines the general principles and parameters of business activities for all types of organizations, is supplemented by legal acts regulating transnational business activities.

In this paragraph, we will formulate an approximate list of measures to regulate transnational business activities:

1) determining the share of local participation and the sale of part of their income by foreign TNCs in the country where the branch is located;

2) substitution demand: if local companies do not produce a product that serves as a feedstock for production in TNC branches, they must use another local product that can replace the required one;

3) production requirements: a list of products for which incentive measures are applied and a list of prohibited products are established;

4) The requirements for technology transfer provide for the mandatory use of a certain set of technological techniques. The aim of these measures is to encourage local research and development;

5) ensuring a balance in trade: the volume of goods and services imported from a foreign branch of a TNC in a given country should be correlated with the volume of exports;

6) currency restrictions aimed at regulating intermediate imports: an investor should not spend more on materials and components purchased abroad than he receives from exports;

7) direct restrictions on the import of certain goods;

8) mandatory equity participation of local firms in the capital of foreign branches and joint ventures;

9) mandatory recruitment of local staff, including employees and managers;

10) determination of the minimum size of the export.

7. The use of indices and indicators describing the course of the process for the purpose of monitoring and forecasting. We propose to calculate the index of transnationalization of agriculture in the EAEU countries as the arithmetic mean sum of four indicators:

1) The indicator of investment in agriculture of the EAEU countries (Pi).

2) The indicator of agricultural production of the EAEU countries (Ppp).

3) The indicator of gross value added, including the type of economic activity "Agriculture, forestry and fisheries" of the EAEU countries (Ldpe).

4) Labor indicators, the share of people employed in agriculture in the EAEU countries (Pt).

The formula for calculating the index of transnationalization of agriculture in the EAEU countries is presented below:

$$
\text { ITag }=\mathrm{Pi}+\mathrm{Ppp}+\text { Ldpe }+\mathrm{Pt} / 4 .
$$

1) The indicator of investments in agriculture of the EAEU countries. To calculate this indicator, information on the volume of investments in fixed assets of agriculture in the EAEU countries is required (Table 1). The information is presented in the statistical collection Statistics of the Eurasian Economic Union [13,14]. 
Table 1. Indices of the volume of investments in fixed assets of agriculture (as a percentage of the total volume of investments in fixed assets). Developed and calculated by the authors.

\begin{tabular}{|l|c|c|c|c|}
\hline \multicolumn{1}{|c|}{ Country } & $\mathbf{2 0 1 6}$ & $\mathbf{2 0 1 7}$ & $\mathbf{2 0 1 8}$ & $\mathbf{2 0 1 9}$ \\
\hline Armenia & 5.8 & 7.6 & 4.9 & 4.2 \\
\hline Belarus & 10.3 & 11.6 & 11.2 & 11.7 \\
\hline Kazakhstan & 3.3 & 4.0 & 3.3 & 3.9 \\
\hline Kyrgyzstan & 0.8 & 0.9 & 2.0 & 2.0 \\
\hline Russia & 4.2 & 4.4 & 4.4 & 4.3 \\
\hline
\end{tabular}

It is necessary to calculate the arithmetic mean index of the volume of investments in fixed assets of agriculture in the EAEU countries (Table 2).

Table 2. Arithmetic mean of the index of the volume of investments in fixed assets of agriculture in the EAEU countries, \%. Developed and calculated by the authors.

\begin{tabular}{|l|c|c|c|c|}
\hline \multicolumn{1}{|c|}{ Indicator } & $\mathbf{2 0 1 6}$ & $\mathbf{2 0 1 7}$ & $\mathbf{2 0 1 8}$ & $\mathbf{2 0 1 9}$ \\
\hline $\begin{array}{l}\text { Indicator of investment in } \\
\text { agriculture of the EAEU } \\
\text { countries }(\mathrm{Pi})\end{array}$ & 4.9 & 5.7 & 5.2 & 5.2 \\
\hline
\end{tabular}

2) The indicator of agricultural production of the EAEU countries. Table 3 provides information on agricultural production (millions of US dollars). Table 4 shows the share of the EAEU countries in agricultural production.

Table 3. Agricultural production (millions of US dollars). Developed and calculated by the authors.

\begin{tabular}{|l|c|c|c|c|}
\hline \multicolumn{1}{|c|}{ Country } & $\mathbf{2 0 1 6}$ & $\mathbf{2 0 1 7}$ & $\mathbf{2 0 1 8}$ & $\mathbf{2 0 1 9}$ \\
\hline Armenia & 1828 & 1882 & 1928 & 1851 \\
\hline Belarus & 7752 & 9333 & 9236 & 9987 \\
\hline Kazakhstan & 10818 & 12553 & 13048 & 13698 \\
\hline Kyrgyzstan & 2824 & 3028 & 2977 & 3152 \\
\hline Russia & 76418 & 87596 & 81862 & 91273 \\
\hline EAEU & 99640 & 114392 & 109051 & 119961 \\
\hline
\end{tabular}

Table 4. Share of the EAEU countries in agricultural production, \%. Developed and calculated by the authors.

\begin{tabular}{|l|c|c|c|c|}
\hline \multicolumn{1}{|c|}{ Country } & $\mathbf{2 0 1 6}$ & $\mathbf{2 0 1 7}$ & $\mathbf{2 0 1 8}$ & $\mathbf{2 0 1 9}$ \\
\hline Armenia & 1.8 & 1.6 & 1.8 & 1.5 \\
\hline Belarus & 7.8 & 8.2 & 8.5 & 8.3 \\
\hline Kazakhstan & 10.9 & 11.0 & 12.0 & 11.4 \\
\hline Kyrgyzstan & 2.8 & 2.6 & 2.7 & 2.6 \\
\hline Russia & 76.7 & 76.6 & 75.1 & 76.1 \\
\hline EAEU & 100.0 & 100.0 & 100.0 & 100.0 \\
\hline
\end{tabular}

Next, it is necessary to calculate the arithmetic mean of the share of the EAEU countries in agricultural production (Table 5).

Table 5. Arithmetic mean of the indicator share of agricultural production, $\%$. Developed and calculated by the authors.

\begin{tabular}{|l|c|c|c|c|}
\hline \multicolumn{1}{|c|}{ Indicator } & $\mathbf{2 0 1 6}$ & $\mathbf{2 0 1 7}$ & $\mathbf{2 0 1 8}$ & $\mathbf{2 0 1 9}$ \\
\hline $\begin{array}{l}\text { The rate of production of } \\
\text { agricultural products of the } \\
\text { EAEU countries (PPP) }\end{array}$ & 20 & 20 & 20 & 20 \\
\hline
\end{tabular}

3) The indicator gross value added and the type of economic activity "Agriculture, forestry and fisheries" of the EAEU countries (Ldpe). 
Gross value added reflects the formation of primary income as a result of the production process of goods and services. Table 6 provides information on the gross value added and the type of economic activity "Agriculture, forestry and fisheries" of the EAEU countries.

Table 6. Gross value added and type of economic activity "Agriculture, forestry and fisheries" of the EAEU countries. Developed and calculated by the authors.

\begin{tabular}{|l|c|c|c|c|c|c|c|c|}
\hline \multirow{2}{*}{ Country } & \multicolumn{3}{|c|}{ gross value added } & \multicolumn{4}{c|}{ Foreign economic activity } \\
agriculture \\
\hline Year & 2016 & 2017 & 2018 & 2019 & 2016 & 2017 & 2018 & 2019 \\
\hline Armenia & 90.1 & 88.7 & 89.4 & 88.7 & 17.4 & 16.0 & 12.9 & 13.0 \\
\hline Belarus & 86.3 & 85.8 & 85.7 & 86.9 & 6.9 & 9.7 & 7.6 & 7.8 \\
\hline Kazakhstan & 95.4 & 93.1 & 93.8 & 93.0 & 5.6 & 4.5 & 4.4 & 4.5 \\
\hline Kyrgyzstan & 87.1 & 86.9 & 86.9 & 87.6 & 12.8 & 12.5 & 12.7 & 12.1 \\
\hline Russia & 90.1 & 90.3 & 89.6 & 89.6 & 3.8 & 3.6 & 3.4 & 3.4 \\
\hline The EEU & 90.3 & 90.5 & 89.9 & 89.8 & 4.4 & 3.9 & 3.7 & 3.7 \\
\hline
\end{tabular}

4) Labor indicators, the share of people employed in agriculture in the EAEU countries $(\mathrm{Pt})$. To calculate labor indicators, the share of people employed in agriculture in the EAEU countries, the following information is required (Table 7).

Table 7. The number of rural population of the EAEU countries (at the beginning of the year; thousands of people). Developed and calculated by the authors.

\begin{tabular}{|l|c|c|c|c|}
\hline \multicolumn{1}{|c|}{ Country } & $\mathbf{2 0 1 6}$ & $\mathbf{2 0 1 7}$ & $\mathbf{2 0 1 8}$ & $\mathbf{2 0 1 9}$ \\
\hline Armenia & 1092.6 & 1085.7 & 1077.9 & 1072.4 \\
\hline Belarus & 2129.3 & 2103.9 & 2079.7 & 2046.0 \\
\hline Kazakhstan & 7635.3 & 7586.7 & 7647.5 & 7697.4 \\
\hline Kyrgyzstan & 3989.9 & 4068.3 & 4134.7 & 4215.8 \\
\hline Russia & 37887.3 & 37772.0 & 37555.5 & 37336.2 \\
\hline EAEU & 52731.4 & 52613.6 & 52493.3 & 52366.8 \\
\hline
\end{tabular}

The share of people employed in agriculture in the EAEU countries is shown in Table 8.

Table 8 . The share of the rural population of the EAEU countries, \%. Developed and calculated by the authors.

\begin{tabular}{|l|c|c|c|c|}
\hline \multicolumn{1}{|c|}{ Country } & $\mathbf{2 0 1 6}$ & $\mathbf{2 0 1 7}$ & $\mathbf{2 0 1 8}$ & $\mathbf{2 0 1 9}$ \\
\hline Armenia & 2.1 & 2.1 & 2.1 & 2.0 \\
\hline Belarus & 4.0 & 4.0 & 4.0 & 3.9 \\
\hline Kazakhstan & 14.5 & 14.4 & 14.6 & 14.7 \\
\hline Kyrgyzstan & 7.6 & 7.7 & 7.9 & 8.1 \\
\hline Russia & 71.8 & 71.8 & 71.5 & 71.3 \\
\hline EAEU & 100.0 & 100.0 & 100.0 & 100.0 \\
\hline
\end{tabular}

The calculation of the arithmetic mean of the share of the rural population of the EAEU countries is presented in Table 9.

Table 9. Arithmetic mean of the rural population of the EAEU countries, \%. Developed and calculated by the authors.

\begin{tabular}{|l|c|c|c|c|}
\hline \multicolumn{1}{|c|}{ Indicator } & $\mathbf{2 0 1 6}$ & $\mathbf{2 0 1 7}$ & $\mathbf{2 0 1 8}$ & $\mathbf{2 0 1 9}$ \\
\hline $\begin{array}{l}\text { Labor indicators. the share of } \\
\text { people employed in } \\
\text { agriculture of the EAEU } \\
\text { countries (Pt) }\end{array}$ & 20.0 & 20.0 & 20.0 & 19.2 \\
\hline
\end{tabular}

We will summarize all the indicators for calculating the index of transnationalization of agriculture in the EAEU countries in one table (Table 10) 
Table 10. Summary table of indicators for calculating the index of transnationalization of agriculture in the EAEU countries, \%. Developed and calculated by the authors.

\begin{tabular}{|l|c|c|c|c|}
\hline \multicolumn{1}{|c|}{ Indicator } & $\mathbf{2 0 1 6}$ & $\mathbf{2 0 1 7}$ & $\mathbf{2 0 1 8}$ & $\mathbf{2 0 1 9}$ \\
\hline $\begin{array}{l}\text { Indicator of investment in agriculture of the } \\
\text { EAEU countries (Pi) }\end{array}$ & 4.9 & 5.7 & 5.2 & 5.2 \\
\hline $\begin{array}{l}\text { The rate of production of agricultural products } \\
\text { of the EAEU countries (PPP) }\end{array}$ & 20 & 20 & 20 & 20 \\
\hline $\begin{array}{l}\text { Indicator gross value added and type of } \\
\text { economic activity "Agriculture. forestry and } \\
\text { fisheries" of the EAEU countries (Ldpe) }\end{array}$ & 4.4 & 3.9 & 3.7 & 3.7 \\
\hline $\begin{array}{l}\text { Labor indicators. the share of people employed } \\
\text { in agriculture of the EAEU countries (Pt) }\end{array}$ & 20.0 & 20.0 & 20.0 & 19.2 \\
\hline
\end{tabular}

Figure 3 clearly illustrates that the index of transnationalization of agriculture in the EAEU countries is declining. The downward trend of the index is mainly due to a decrease in the Ldpe (gross value added) indicator.

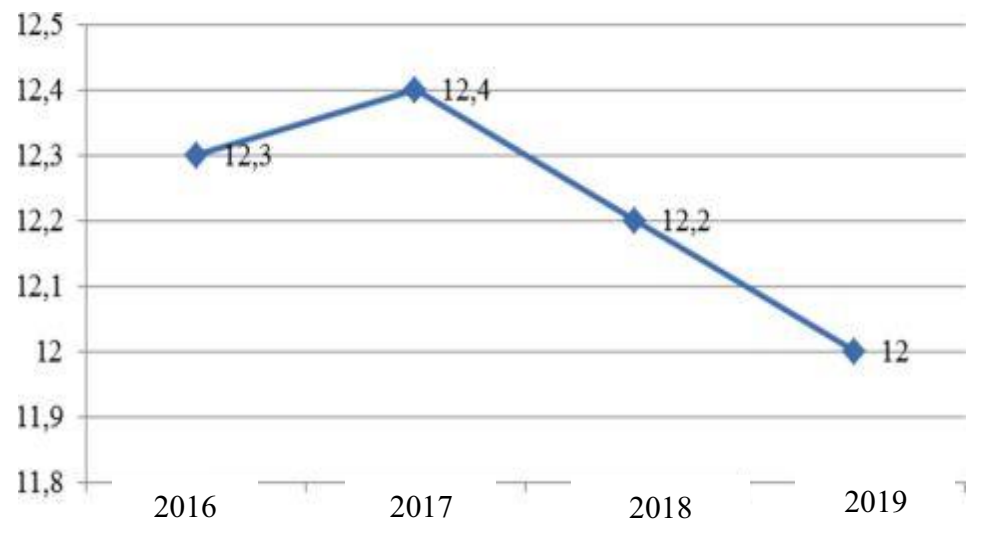

Fig. 3. Dynamics of the transnationalization index of agriculture in the EAEU countries, \%. Note: developed by the authors.

The index of transnationalization of agriculture of the EAEU countries reached its maximum value in 2017. If we study the world practice of calculating this indicator, the average index of transnationalization of developed countries is about $15 \%$. The maximum value is $35 \%$ in New Zealand, Belgium and Luxembourg, and $7 \%$ in the US. In the group of developing countries, the average transnationalization index is about $17 \%$. In the countries of Central and Eastern Europe, the average transnationalization index is $10 \%$. The analysis and monitoring of this indicator, despite the short period of existence of the EEA by world standards, will allow us to monitor and exert a managerial impact on the processes of integration and interpenetration of the economic complexes of the Union countries in the context of inclusion in the global economic systems (Fig.4) $[15,16]$. 


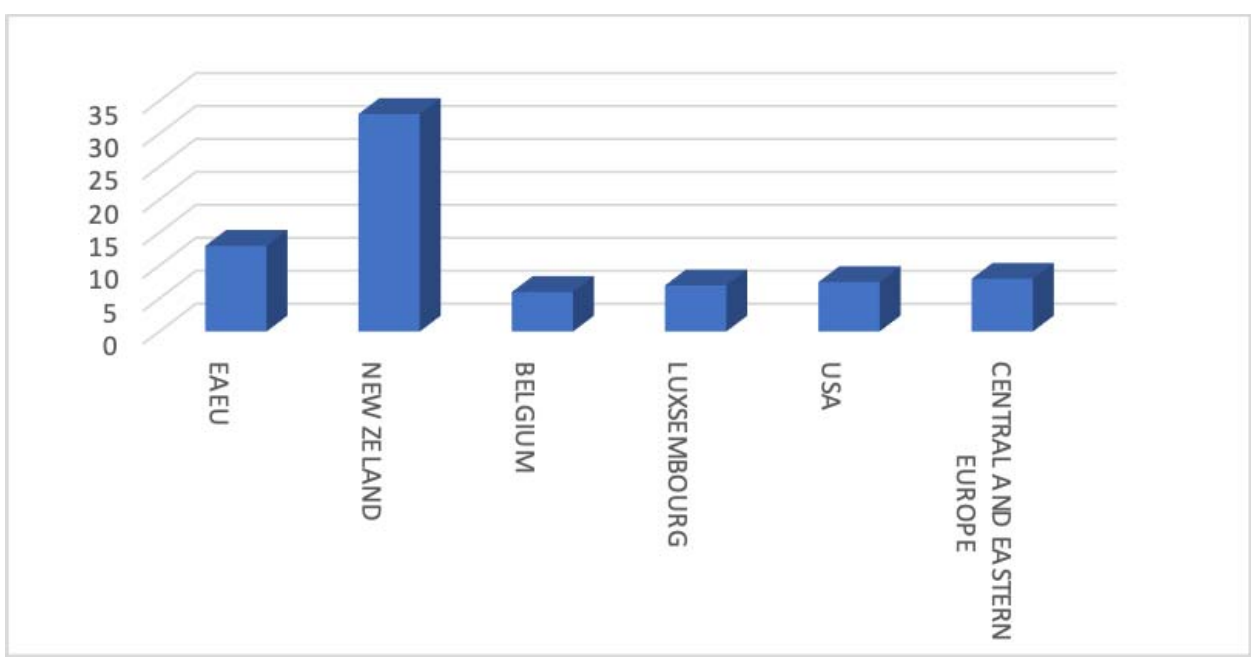

Fig. 4. The index of transnationalization in the regions of the world in 2017. Note: developed by the authors.

The above provisions reflect the authors ' point of view, what should be a timely response to the current trends of transnationalization, integration of national economies into global systems, development of TNCs, which are a complex and constantly developing phenomenon in the system of world economic relations, requiring special attention from the state and international control, especially in the context of the structural and financial crisis.

\section{Conclusion}

In conclusion, it should be noted that the processes of transnationalization and integration of the agrarian sector of the Eurasian economic Union countries affected by economic instability, volatility in financial and energy markets, complex political conditions, in conditions of high interdependence especially painful impact on emerging economies. The development of theoretical and methodological provisions for the management of the processes of transnationalization and integration will simplify this process and increase the efficiency of management.

\section{References}

1. R. Yanbykh, V. Saraikin, Z. Lerman, Russian Journal of Economics 6(1), 26-41 (2020)

2. S. Podgorskaya, S. Schitov, E3S Web of Conferences. Innovative Technologies in Science and Education (ITSE-2020) 210, 14001 (2020)

3. M. Kholodova, S. Podgorskaya, E3S Web of Conferences. Innovative Technologies in Science and Education (ITSE-2020) 210, 11007 (2020) doi: $10.1051 / \mathrm{e} 3$ sconf/202021011007

4. W.M. Liefert, O. Liefert, Russian Journal of Economics 6(1), 56-70 (2020) https://doi.org/10.32609/j.ruje.6.50308

5. D. Panagiotou, Agricultural Economics Review 18(2), 112-125 (2017)

6. O.V. Shik, Russian Journal of Economics 6(1), 42-55 (2020) https://doi.org/10.32609/j.ruje.6.49756 
7. J. Bijman, P. Pyykkönen, P. Ollila, The Dovenschmidt Quarterly 2014(4), 168-178 (2014) DOI: $10.5553 / \mathrm{DQ} / 221199812014002004005$

8. P. Baker, S. Friel, Global Health 12, 80 (2016) https://doi.org/10.1186/s12992-0160223-3

9. C.A. Monteiro, G. Cannon, PLoS Med. 9(7), e1001252 (2012) https://doi.org/10.1371/journal.pmed.1001252

10. Kerstin Schmidt, International Review of Sociology 29(2), 197214 (2019) DOI: 10.1080/03906701.2019.1641274

11. Helder Ferreira Vale, Rev. bras. polít. int. 61(1), e010 (2018) https://doi.org/10.1590/0034-7329201800110

12. H. Bernstein, Journal of Peasant Studies 43(3), 611-47 (2016) doi: https://doi.org/10.1080/03066150.2015.1101456

13. D. Cáceres, Journal of Agrarian Change 15(1), 116-147 (2015) doi: https://doi.org/10.1111/joac.12057

14. B. Cousins, S.M. Borras Jr., S. Sauer, J.Ye. Globalizations 15(1), 1-11 (2018) doi: https://doi.org/10.1080/14747731.2018.1429104

15. F. Escher, S. Schneider, J.Ye. Globalizations 15(1), 92-113 (2018) doi: https://doi.org/10.1080/14747731.2017.1373980

16. K. Hopewell, Critical Perspectives on International Business 10(4), 291-309 (2014) doi: https://doi.org/10.1108/cpoib-03-2014-0019 